\title{
Comparison of pentraxin-3 and ischemia-modified albumin with troponin in early diagnosis of acute coronary syndrome
}

\author{
Demir $\mathrm{MT}^{1}$, Baydin $\mathrm{A}^{2}$, Amanvermez $\mathrm{R}^{3}$, Erenler $\mathrm{AK}^{4}$, Güzel $\mathrm{M}^{1}$, Yücel $\mathrm{O}^{5}$ \\ Ondokuz Mayis University, Faculty of Medicine, Department of Emergency Medicine, Samsun, Turkey. \\ ahmetbaydn@yahoo.com
}

\begin{abstract}
INTRODUCTION: In this study, our aim was to evaluate clinical utilities of Pentraxin 3 (PTX3) and Ischemiamodified Albumin (IMA) in diagnosis of acute coronary syndrome (ACS) and compare these two biomarkers with a conventional diagnostic marker, cardiac troponin I (cTnl).

MATERIALS AND METHODS: Sixty adult patients with ACS diagnosis were involved into this prospective study. Additionally, 20 healthy subjects were determined as control group (Group IV). Patients were divided into 3 groups as follows: Patients with Acute Myocardial Infarction (STEMI Group, $n=20$, Group I), patients without ST elevation but with elevated cTnl levels (NSTEMI Group, $n=20$, Group II), and patients with unstable angina pectoris (USAP Group, $n=20$, Group III). Blood measurements were obtained for each marker at admission and in the 4th hour.

RESULTS: Troponin level was significantly different between groups I and II at both admission and in the 4th hour. Additionally, PTX 3 level was significantly different at admission and 4th hour between groups II and III. CONCLUSION: This study revealed that CTnl is the most sensitive test in ACS diagnosis at the admission to Emergency Department. Our results also revealed that PTX 3 may be a useful diagnostic tool for ACS at admission, however, IMA alone cannot be used for diagnosis of ACS. Similarly, in the 4th hour, cTnl was found to be the most useful marker in ACS diagnosis, however, PTX 3 and IMA were found to be inadequate for diagnosis of ACS (Tab. 3, Ref. 19). Text in PDF www.elis.sk.

KEY WORDS: acute coronary syndrome, cardiac troponin i, ischemia-modified albumin, pentraxin 3, emergency department.
\end{abstract}

\section{Introduction}

Acute coronary syndrome (ACS) involves a broad spectrum of complaints from angina pectoris to irreversible myocardial damage resulting in acute myocardial infarction (AMI) (1). Recently, many potential biomarkers have been studied for the early and appropriate diagnosis of AMI. Cardiac troponin I (cTnI) and troponin $\mathrm{T}$ are commonly used for determining the extent of cardiac muscle injury in AMI. However, studies for novel early diagnostic biomarkers are still ongoing (2).

Ischemia-modified albumin (IMA) is a marker formed after damage in the $\mathrm{N}$-terminal region of albumin. The causes of the increases in IMA have been shown to be endothelial or extracellular hypoxia, acidosis, and free oxygen radicals (34).

${ }^{1}$ Department of Emergency Medicine, Samsun Education and Research Hospital, Samsun, Turkey, ${ }^{2}$ Department of Emergency Medicine, Faculty of Medicine, Ondokuz Mayis University, Samsun, Turkey, ${ }^{3}$ Department of Medical Biochemistry, Faculty of Medicine, Ondokuz Mayis University, Samsun, Turkey, ${ }^{4}$ Department of Emergency Medicine, Faculty of Medicine, Hitit University, Corum, Turkey, and ${ }^{5}$ Department of Cardiology, Samsun Education and Research Hospital, Samsun, Turkey

Address for correspondence: A. Baydin, MD, Ondokuz Mayis University, Faculty of Medicine, Department of Emergency Medicine, Kurupelit, 55139 Samsun, Turkey.

Phone: +90.362.3121919/2096, Fax: +90.362.4576041
Similar to IMA, Pentraxin 3 (PTX 3) is known to be released as a specific response to vascular damage and PTX 3 levels are likely to be strongly related to later stages of atherosclerosis (5). In this article, our aim was to investigate the usefulness of IMA and PTX 3 in the early diagnosis of AMI and compare their utility with conventional marker, cTnI.

\section{Materials and methods}

After ethical approval form Local Ethics Committee, 60 adult patients with ACS diagnosis admitted to Coronary Intensive Care Unit were involved into this prospective study. Additionally, 20 healthy subjects formed a control group. Patients with ACS were divided into 3 groups as follows: Patients with AMI confirmed by ST elevation on serial electrocardiograms (ECGs) and cTnI measurements (STEMI Group, $n=20$, Group I), patients without ST elevation but with elevated cTnI levels (NSTEMI Group, $\mathrm{n}=$ 20, Group II), and patients with unstable angina pectoris (USAP Group, $n=20$, Group III). Control group was named as Group IV.

Patients with chronic obstructive pulmonary disease, renal failure, collagen tissue disease, vasculitis, depression, somatization disorder and patients with a medical history of coronary angiography, coronary by-pass and open heart surgery were excluded in order to avoid false positive cTnI levels. 
Blood samples of the patients were evaluated at admission and in the 4th hour of follow-up. Blood samples for IMA and PTX 3 were taken at admission and in the 4th and were centrifuged at $3500 \mathrm{rpm}$ for 15 minutes, and serum samples were stored at -80 ${ }^{\circ} \mathrm{C}$ until analysis.

CK-MB and cTnI levels were measured in serum by Simens ADVIA Centaur Cp analyzers in emergency laboratory.

Serum PTX 3 level was measured by ELISA using a kit (USCN Life Science Inc. Cloud-Clone Corp. Houston, USA, Lot No: L140205003) and IMA was also measured by ELISA using a kit (Cusabio Biotech Co.,ltd. Wuhan, China, Lot No:W22169285). For this measurement, sandwich immunoassay technique was used.

\section{Statistical analysis}

For statistical analyses, SPSS 17.0 programme was used. Data are presented as arithmetic mean \pm standard deviation and median (minimum-maximum) values. For evaluation of normality, Shapiro Wilk test was used. In comparison of groups, One Way ANOVA was used for normal distribution and Kruskal-Wallis variance analysis was used for non-normal distribution. For comparison of normally distributed two groups, Tukey was used for homogenous variance and Tamhane test was used for heterogeneous variance.
Tab. 1. Groups according to demographic findings.

\begin{tabular}{|c|c|c|c|}
\hline \multirow{2}{*}{ Groups } & \multicolumn{2}{|c|}{ Gender } & \multirow{2}{*}{ Age \pm SD } \\
\hline & Male & Female & \\
\hline Group I & 17 (85\%) & 3 (15\%) & $58.5 \pm 19.1$ \\
\hline Group II & 15 (75\%) & $5(25 \%)$ & $63.6 \pm 15.4$ \\
\hline Group III & 17 (85\%) & 3 (15\%) & $52.8 \pm 13.3$ \\
\hline Group IV & 14 (70\%) & $6(30 \%)$ & $27.7 \pm 9.5$ \\
\hline
\end{tabular}

For comparison of two normally distributed groups, Bonferroni corrected Mann Whitney U test was used. Pearson correlation test was performed to test correlation between normally distributed data and Spearman's correlation test was used for non-normally distributed data. Diagnostic values of the markers were evaluated by Receiver Operating Characteristic (ROC) Analysis and Area Under Curve (AUC). p $<0.05$ was considered statistically significant.

\section{Results}

Demographical and laboratory findings of the groups are summarized in Tables 1 and 2. Troponin level was significantly different in groups I and II at both admission and the 4th hour when

Tab. 2. Laboratory findings of the groups.

\begin{tabular}{|c|c|c|c|c|c|c|c|c|}
\hline \multirow[b]{2}{*}{$\begin{array}{l}\text { Laboratory Findings } \\
\text { (On admission) }\end{array}$} & \multicolumn{2}{|c|}{$\begin{array}{l}\text { Group I } \\
(\mathrm{n}=20)\end{array}$} & \multicolumn{2}{|c|}{$\begin{array}{l}\text { Group II } \\
(\mathrm{n}=20)\end{array}$} & \multicolumn{2}{|c|}{$\begin{array}{c}\text { Group III } \\
(\mathrm{n}=20)\end{array}$} & \multicolumn{2}{|c|}{$\begin{array}{c}\text { Group IV (Controls) } \\
(\mathrm{n}=20)\end{array}$} \\
\hline & $\begin{array}{c}\text { Arithmetic } \\
\text { Mean } \pm \text { Standard } \\
\text { Deviation }\end{array}$ & $\begin{array}{c}\text { Median } \\
\text { (Min-Max) }\end{array}$ & $\begin{array}{c}\text { Arithmetic } \\
\text { Mean } \pm \text { Standard } \\
\text { Deviation }\end{array}$ & $\begin{array}{c}\text { Median } \\
\text { (Min-Max) }\end{array}$ & $\begin{array}{c}\text { Arithmetic } \\
\text { Mean } \pm \text { Standard } \\
\text { Deviation }\end{array}$ & $\begin{array}{c}\text { Median } \\
\text { (Min-Max) }\end{array}$ & $\begin{array}{c}\text { Arithmetic } \\
\text { Mean } \pm \text { Standard } \\
\text { Deviation }\end{array}$ & $\begin{array}{c}\text { Median } \\
\text { (Min-Max) }\end{array}$ \\
\hline $\begin{array}{l}\text { White blood cell } \\
\text { (3.7-9.7 thousand/uL) }\end{array}$ & $12.4 \pm 3.5$ & $\begin{array}{c}10.7 \\
(8.3-17.5) \\
\end{array}$ & $10.6 \pm 3.2$ & $\begin{array}{c}10.7 \\
(5.8-18.4) \\
\end{array}$ & $9.2 \pm 2.5$ & $\begin{array}{c}8.5 \\
(4.6-13.6) \\
\end{array}$ & $7.1 \pm 1.5$ & $\begin{array}{c}6.7 \\
(4.9-10.9) \\
\end{array}$ \\
\hline $\begin{array}{l}\text { Haemoglobin } \\
(13.3-17.2 \text { g/dL) } \\
\end{array}$ & $14.36 \pm 2.4$ & $\begin{array}{c}14.9 \\
(9.3-17.2) \\
\end{array}$ & $13.9 \pm 2.0$ & $\begin{array}{c}14.4 \\
(9.4-17.1) \\
\end{array}$ & $14.4 \pm 1.5$ & $\begin{array}{c}14.7 \\
(12.0-17.6) \\
\end{array}$ & $13.8 \pm 1.6$ & $\begin{array}{c}13.7 \\
(11.4-16.5) \\
\end{array}$ \\
\hline $\begin{array}{l}\text { Platelet } \\
\text { (179-373 thousand/uL) }\end{array}$ & $238.9 \pm 50.2$ & $\begin{array}{c}239.5 \\
(158.0-346.0) \\
\end{array}$ & $240.8 \pm 66.2$ & $\begin{array}{c}232.5 \\
(161.0-394.0) \\
\end{array}$ & $246.0 \pm 112.7$ & $\begin{array}{c}224.5 \\
(42.0-538.0) \\
\end{array}$ & $249.5 \pm 48.4$ & $\begin{array}{c}244.0 \\
(180.0-342.0) \\
\end{array}$ \\
\hline $\begin{array}{l}\text { Glucose } \\
(70-110 \mathrm{mg} / \mathrm{dL})\end{array}$ & $176.2 \pm 84.8$ & $\begin{array}{c}136.0 \\
(84.0-401.0) \\
\end{array}$ & $155.4 \pm 71.9$ & $\begin{array}{c}130.5 \\
(84.0-380.0) \\
\end{array}$ & $159.7 \pm 86.3$ & $\begin{array}{c}122.0 \\
(85.0-396.0) \\
\end{array}$ & $94.9 \pm 12.2$ & $\begin{array}{c}93.5 \\
(72.0-121.0) \\
\end{array}$ \\
\hline $\begin{array}{l}\text { BUN } \\
(5-24 \mathrm{mg} / \mathrm{dL}) \\
\end{array}$ & $17.8 \pm 7.2$ & $\begin{array}{c}16.0 \\
(9.0-44.0)\end{array}$ & $18.0 \pm 4.7$ & $\begin{array}{c}17.0 \\
(10.0-27.0) \\
\end{array}$ & $19.4 \pm 12.3$ & $\begin{array}{c}16.0 \\
(8.0-63.0) \\
\end{array}$ & $10.9 \pm 3.3$ & $\begin{array}{c}10.0 \\
(4.0-19.0) \\
\end{array}$ \\
\hline $\begin{array}{l}\text { Creatine } \\
(0.4-1.4 \mathrm{mg} / \mathrm{dL})\end{array}$ & $0.9 \pm 0.2$ & $\begin{array}{c}0.9 \\
(0.5-1.5) \\
\end{array}$ & $0.9 \pm 0.2$ & $\begin{array}{c}0.9 \\
(0.50-1.40) \\
\end{array}$ & $0.9 \pm 0.2$ & $\begin{array}{c}0.9 \\
(0.6-1.4) \\
\end{array}$ & $0.8 \pm 0.2$ & $\begin{array}{c}0.9 \\
(0.4-1.0)\end{array}$ \\
\hline $\begin{array}{l}\text { AST } \\
(8-46 \text { UL) }\end{array}$ & $48.5 \pm 37.8$ & $\begin{array}{c}34.0 \\
(12.0-143.0) \\
\end{array}$ & $56.30 \pm 48.20$ & $\begin{array}{c}47.00 \\
(22.0-233.0)\end{array}$ & $25.7 \pm 12.8$ & $\begin{array}{c}22.5 \\
(10.0-57.0)\end{array}$ & $18.95 \pm 3.25$ & $\begin{array}{c}18.0 \\
(14.0-26.0) \\
\end{array}$ \\
\hline $\begin{array}{l}\text { ALT } \\
(7-46 \text { UL) }\end{array}$ & $34.4 \pm 14.5$ & $\begin{array}{c}32.0 \\
(15.0-67.0) \\
\end{array}$ & $30.6 \pm 12.6$ & $\begin{array}{c}28.5 \\
(14.0-64.0) \\
\end{array}$ & $28.9 \pm 21.6$ & $\begin{array}{c}22.5 \\
(4.0-96.0) \\
\end{array}$ & $19.7 \pm 8.8$ & $\begin{array}{c}18.5 \\
(11.0-43.0) \\
\end{array}$ \\
\hline $\begin{array}{l}\text { Creatin Kinase } \\
\text { (35-195 UL) }\end{array}$ & $339.6 \pm 358.7$ & $\begin{array}{c}139.0 \\
(71.0-1239.0) \\
\end{array}$ & $428.9 \pm 526.9$ & $\begin{array}{c}328.5 \\
(39.9-2456.0) \\
\end{array}$ & $218.3 \pm 345.5$ & $\begin{array}{c}101.0 \\
(34.0-1484.0)\end{array}$ & $171.2 \pm 154.2$ & $\begin{array}{c}137.5 \\
(64.0-796.0)\end{array}$ \\
\hline $\begin{array}{l}\text { CK-MB } \\
(0-25 \mathrm{mg} / \mathrm{dL})\end{array}$ & $48.3 \pm 42.1$ & $\begin{array}{c}37.0 \\
(2.0-200.0) \\
\end{array}$ & $67.3 \pm 99.8$ & $\begin{array}{c}40.0 \\
(19.0-479.0) \\
\end{array}$ & $25.6 \pm 13.0$ & $\begin{array}{c}20.5 \\
(3.0-51.0) \\
\end{array}$ & $14.4 \pm 1.31$ & $\begin{array}{c}14.0 \\
(12.0-18.0)\end{array}$ \\
\hline $\begin{array}{l}\text { Calcium } \\
(8.6-10.0 \mathrm{mg} / \mathrm{dL})\end{array}$ & $9.42 \pm 0.7$ & $\begin{array}{c}9.5 \\
(7.9-11.1) \\
\end{array}$ & $9.5 \pm 0.5$ & $\begin{array}{c}9.40 \\
(8.3-10.3) \\
\end{array}$ & $9.8 \pm 0.7$ & $\begin{array}{c}9.55 \\
(8.8-11.6) \\
\end{array}$ & $9.9 \pm 0.6$ & $\begin{array}{c}9.8 \\
(9.0-11.8) \\
\end{array}$ \\
\hline $\begin{array}{l}\text { Sodium } \\
(135-145 \mathrm{mEq} / \mathrm{L})\end{array}$ & $138.8 \pm 3.7$ & $\begin{array}{c}139.5 \\
(132.0-145.0) \\
\end{array}$ & $139.3 \pm 2.8$ & $\begin{array}{c}139.0 \\
(134.0-145.0) \\
\end{array}$ & $139.6 \pm 2.9$ & $\begin{array}{c}139.5 \\
(134.0-145.0)\end{array}$ & $140.1 \pm 1.5$ & $\begin{array}{c}140.0 \\
(136.0-142.0) \\
\end{array}$ \\
\hline $\begin{array}{l}\text { Potassium } \\
(3.5-5.5 \mathrm{mEq} / \mathrm{L})\end{array}$ & $4.0 \pm 0.5$ & $\begin{array}{c}3.90 \\
(3.3-5.3) \\
\end{array}$ & $4.3 \pm 0.5$ & $\begin{array}{c}4.2 \\
(3.40-5.5) \\
\end{array}$ & $4.3 \pm 0.4$ & $\begin{array}{c}4.20 \\
(3.70-4.90) \\
\end{array}$ & $4.30 \pm 0.34$ & $\begin{array}{c}4.23 \\
(3.8-5.0) \\
\end{array}$ \\
\hline $\begin{array}{l}\text { Clor } \\
(99-110 \mathrm{mEq} / \mathrm{L})\end{array}$ & $104.0 \pm 4.2$ & $\begin{array}{c}105.0 \\
(96.0-113.0)\end{array}$ & $105.9 \pm 3.9$ & $\begin{array}{c}105.5 \\
(97.0-115.0)\end{array}$ & $105.4 \pm 3.9$ & $\begin{array}{c}106.0 \\
(97.0-112.0)\end{array}$ & $104.0 \pm 1.8$ & $\begin{array}{c}104.5 \\
(101.0-107.0)\end{array}$ \\
\hline
\end{tabular}


Tab. 3. Comparison of the markers on admission and in the 4th hour.

\begin{tabular}{|c|c|c|c|c|c|c|c|c|c|}
\hline \multirow[b]{2}{*}{ Biomarker } & \multicolumn{2}{|c|}{$\begin{array}{l}\text { Group I } \\
(\mathrm{n}=20)\end{array}$} & \multicolumn{2}{|c|}{$\begin{array}{l}\text { Group II } \\
(\mathrm{n}=20)\end{array}$} & \multicolumn{2}{|c|}{$\begin{array}{l}\text { Group III } \\
(\mathrm{n}=20)\end{array}$} & \multicolumn{2}{|c|}{$\begin{array}{l}\text { Control } \\
(\mathrm{n}=20)\end{array}$} & \multirow[b]{2}{*}{ P value } \\
\hline & $\begin{array}{c}\text { Arithmetic } \\
\text { Mean } \pm \text { Standard } \\
\text { Deviation }\end{array}$ & $\begin{array}{c}\text { Median } \\
\text { (Min-Max) }\end{array}$ & $\begin{array}{c}\text { Arithmetic } \\
\text { Mean } \pm \text { Standard } \\
\text { Deviation }\end{array}$ & $\begin{array}{c}\text { Median } \\
\text { (Min-Max) }\end{array}$ & $\begin{array}{c}\text { Arithmetic } \\
\text { Mean } \pm \text { Standard } \\
\text { Deviation }\end{array}$ & $\begin{array}{c}\text { Median } \\
\text { (Min-Max) }\end{array}$ & $\begin{array}{c}\text { Arithmetic } \\
\text { Mean } \pm \text { Standard } \\
\text { Deviation }\end{array}$ & $\begin{array}{c}\text { Median } \\
\text { (Min-Max) }\end{array}$ & \\
\hline $\begin{array}{l}\text { cTnI (ng/ml) } \\
\text { (On admission) }\end{array}$ & $0.9 \pm 2.4$ & $\begin{array}{c}0.2 \\
(0.1-8.5)\end{array}$ & $2.5 \pm 3.6$ & $\begin{array}{c}1.0 \\
(0.1-15.4)\end{array}$ & $0.01 \pm 0.0$ & $\begin{array}{c}0.01 \\
(0.01-0.01)\end{array}$ & $0.01 \pm 0.0$ & $\begin{array}{c}0.01 \\
(0.01-0.01)\end{array}$ & $\mathrm{p}<0.001$ \\
\hline $\begin{array}{l}\text { cTnI (ng/ml) } \\
\text { (4.hour) }\end{array}$ & $3.3 \pm 4.2$ & $\begin{array}{c}0.9 \\
(0.1-1.1) \\
\end{array}$ & $3.6 \pm 4.6$ & $\begin{array}{c}1.9 \\
(0.1-9.2) \\
\end{array}$ & $0.01 \pm 0.0$ & $\begin{array}{c}0.01 \\
(0.01-.0 .1) \\
\end{array}$ & $0.01 \pm 0.0$ & $\begin{array}{c}0.01 \\
(0.01-0.01) \\
\end{array}$ & $\mathrm{p}<0.001$ \\
\hline $\begin{array}{l}\text { PTX-3 (ng/ml) } \\
\text { (On admission) }\end{array}$ & $7.2 \pm 4.7$ & $\begin{array}{c}6.9 \\
(1.0-5.6)\end{array}$ & $8.9 \pm 5.1$ & $\begin{array}{c}9.6 \\
(1.3-6.6)\end{array}$ & $5.4 \pm 3.5$ & $\begin{array}{c}4.4 \\
(0.8-2.4)\end{array}$ & $1.3 \pm 0.5$ & $\begin{array}{c}1.3 \\
(0.2-1.9)\end{array}$ & $\mathrm{p}<0.001$ \\
\hline $\begin{array}{l}\text { PTX-3 (ng/ml) } \\
\text { (4.hour) }\end{array}$ & $3.3 \pm 4.2$ & $\begin{array}{c}6.5 \\
(0.4-4.9)\end{array}$ & $11.3 \pm 4.6$ & $\begin{array}{c}12.9 \\
(2.5-8.9)\end{array}$ & $7.7 \pm 2.8$ & $\begin{array}{c}7.6 \\
(1.6-2.3)\end{array}$ & $1.5 \pm 0.6$ & $\begin{array}{c}1.5 \\
(0.3-2.1)\end{array}$ & $\mathrm{p}>0.05 ! !$ \\
\hline $\begin{array}{l}\mathrm{IMA}(\mathrm{IU} / \mathrm{ml}) \\
\text { (On admission) }\end{array}$ & $18.6 \pm 12.2$ & $\begin{array}{c}13.7 \\
(8.2-8.7)\end{array}$ & $16.5 \pm 5.2$ & $\begin{array}{c}15.6 \\
(8.2-9.8)\end{array}$ & $21.2 \pm 16.6$ & $\begin{array}{c}15.3 \\
(6.2-7.3)\end{array}$ & $9.9 \pm 1.8$ & $\begin{array}{c}9.7 \\
(3.8-7.2)\end{array}$ & $\mathrm{p}<0.001$ \\
\hline $\begin{array}{l}\text { IMA (IU/ml) } \\
\text { (4.hour) }\end{array}$ & $16.5 \pm 8.3$ & $\begin{array}{c}13.54 \\
(2.1-9.3) \\
\end{array}$ & $15.6 \pm 4.7$ & $\begin{array}{c}14.7 \\
(8.1-8.8) \\
\end{array}$ & $15.9 \pm 7.9$ & $\begin{array}{c}12.9 \\
(0.7-7.5) \\
\end{array}$ & $9.7 \pm 1.7$ & $\begin{array}{c}9.6 \\
(3.6-7.1) \\
\end{array}$ & $\mathrm{p}<0.001$ \\
\hline
\end{tabular}

compared to other groups ( $\mathrm{p}<0.001$ ). Also, PTX 3 level was significantly different at admission and 4th hour in group II when compared to other groups $(\mathrm{p}<0.05)$. Statistical significance could not be shownfor the differences between groups with respect to other biomarkers $(\mathrm{p}>0.05)$.

Comparisons between the groups in respect to biochemical markers are summarized in Table 3.

ROC analysis was performed for biomarkers. AUC value for troponin at admission was found to be 0.863 (95\% CI: 0.771$0.954)(\mathrm{p}<0.05)$. ROC analysis for troponin in the 4th hour revealed an AUC of 1.000 (95\% CI: 1.000-1.000) (p < 0.05).

ROC analysis for PTX 3 at admission revealed an AUC of 0.661 (95\% CI: $0.523-0.800)$ ( $<<0.05)$. AUC for PTX 3 in the 4th hour was found to be 0.563 (95\% CI: 0.418-0.708) ( $\mathrm{p}>0.05$ ).

ROC analysis revealed AUC for IMA at admission and in the 4th hour as 0.479 (95\% CI: 0.317-0.641) (p > 0.05) and 0.554 (95\% CI: 0.388-0.720) ( $>$ > 0.05), respectively.

\section{Discussion}

According to our results, cTnI is the most sensitive test in ACS diagnosis on admission to ED. Our results also revealed while PTX 3 may be a useful diagnostic tool for ACS on admission, IMA alone cannot be used for diagnosis of ACS. Similarly, in the 4th hour, cTnI was found to be the most useful marker in ACS diagnosis, however, PTX 3 and IMA were found to be insufficient for the diagnosis of ACS.

It is well-known in the literature that cardiac troponins play a critical role in the diagnosis of ACS and AMI. Troponin testing is performed widely in patients attending the Emergency Department (ED) for rapid evaluation and exclusion of multiple potential diagnoses simultaneously (6). A rise and/or fall in cardiac troponin with at least one value above the 99th centile of the upper reference limit in the context of symptoms or clinical evidence of AMI has recently been defined as NSTEMI (7). Cardiac troponin remains the gold standard biomarker for the diagnostic evaluation of AMI (2). Compatible with the literature, in our study, cTnI was found to be the best diagnostic tool for ACS either on admission or in the 4th hour.

It was reported that PTX 3 was elevated in the acute phase of AMI and had prognostic significance in those patients (8). PTX 3 was also reported to reflect different aspects of atherosclerosisrelated inflammation, however, the role of PTX 3 in atherosclerosis is not clear (5). Even though the discovery of PTX 3 in the myocardial tissue and the characterization of its role has led to proposing PTX 3 as an early indicator of irreversible myocyte injury in ischemic heart disease (9), plasma level of PTX 3 was reported to increase in patients with AMI after about $7 \mathrm{~h}$ from the onset of symptoms, with a decrease in baseline levels after three days $(10,11)$. In contrary, our results interestingly showed that PTX 3 level was elevated on admission which may be interpreted that PTX 3 is more useful as an early indicator of ACS. The early predictor role of PTX3 may be related to fact that PTX 3 is associated with plaque vulnerability which is the initial phase of AMI (12). In some conditions, PTX 3 may be used in differential diagnosis of NSTEMI and USAP where cTnI is not readily available. However, further studies are needed in this field.

During ischemia, the N-terminus of albumin is altered, possibly as the result of hypoxia, acidosis, free-radical injury, and energy-dependent membrane disruption, decreasing its binding capacity for metals $(13,14)$. There are numerous reports in the literature proposing IMA as a promising marker in ACS diagnosis (3). Sinha et al. reported that the sensitivity of IMA for the diagnosis of ACS is significantly greater than that of ECG and cardiac troponin, used alone or combined (15). However, Aggarwal et al. reported that the IMA assay is a sensitive but not very specific marker for the early detection of myocardial ischemia. IMA levels were found to be significantly higher in patients with chest pain with myocardial ischemia as compared to control groups. They also found that IMA levels were positively correlated with other 
509-512

conventional markers of AMI such as CK-MB and troponin levels. They concluded that the use of IMA alone was not adequate as a marker in diagnosis of ACS and should be used in combination with other markers in order to increase its specificity (16). In our study, IMA was found to be useful neither in ACS diagnosis on admission nor in the 4th hour.

Our results revealed that IMA level correlated with creatine level compatible with the fact that IMA level is affected by renal function. In end-stage renal disease (ESRD) patients, serum IMA levels were found to be high because of anemia, leading to generalized hypoxia. In another study, Türedi et al. reported that IMA levels of ESRD patients, both pre and post-hemodialysis, were significantly higher than those of the control group $(17,18)$. However, another result of our study, correlation of WBC with IMA and PTX needs to be clarified. Previously, Baydin et al. reported that in patients with carbon monoxide poisoning, when hypoxic condition is causing damage to oxygen dependent tissues such as heart and brain, PTX3 and IMA were not superior to cTnI (19). Their results are in compliance with ours that these two markers cannot be used as independent predictors of ACS.

\section{Conclusion}

Superiority of troponins, particularly cTnI, in the diagnosis of ACS is still accepted. Serum PTX 3 and IMA measurements alone do not reflect cardiovascular status of patients. PTX 3 may differentiate patients with NSTEMI and USAP. However, cTnI has advantage of being readily available in most of the EDs.

\section{References}

1. Kocabaş R, Erenler AK, Yetim M, Doğan T, Erdemli HK. Butyrylcholinesterase as an additional marker in the diagnostic network of acute myocardial infarction. Labor Med 2016; 40: 147-152.

2. Ay MO, Erenler AK, Dogan T, Yetim M. Diagnostic value of copeptin in acute myocardial infarction. Eur Rev Med Pharmacol Sci 2017; 21: $1576-1582$.

3. Erenler AK, Yardan T, Kati C, Altuntaş M, Türedi S. Role of ischemia-modified albumin in clinical practice. Labor Med 2015; 39: 241-247.

4. Erturk E, Cekic B, Geze S, Kosucu M, Coskun I et al. Comparison of the effect of propofol and $\mathrm{N}$-acetylcysteine in preventing ischaemiareperfusion injury. Eur J Anaesthesiol 2009; 26: 279-84.

5. Jenny NS, Blumenthal RS, Kronmal RA, Rotter JI, Siscovick DS, Psaty BM. Associations of pentraxin 3 with cardiovascular disease: The Multi-Ethnic Study of Atherosclerosis. J Thromb Haemost 2014; 12: 9991005.
6. Shah ASV, Ferry AV, Mills NL. Cardiac Biomarkers and the Diagnosis of Myocardial Infarction in Women. Curr Cardiol Rep 2017; 19: 40. DOI: 10.1007/s11886-017-0839-9.

7. Thygesen K, Alpert JS, Jaffe AS, Simoons ML, Chaitman BR et al. Third universal definition of myocardial infarction. Circulation. 2012; 126: 2020-2035.

8. Latini R, Maggioni AP, Peri G, Gonzini L, Lucci D, Mocarelli P et al. Prognostic significance of the long pentraxin PTX3 in acute myocardial infarction. Circulation 2004; 110: 2349-2354.

9. Fornai F, Carrizzo A, Forte M, Ambrosio M, Damato A et al. The inflammatory protein Pentraxin 3 in cardiovascular disease. Immun Ageing 2016; 13: 25. DOI: 10.1186/s12979-016-0080-1.

10. Peri G, Introna M, Corradi D, Iacuitti G, Signorini S, Avanzini F et al. PTX3, a prototypical long pentraxin, is an early indicator of acute myocardial infarction in humans. Circulation 2000; 102: 636-641.

11. Duran S, Duran I, Kaptanagasi FA, Nartop F, Ciftci H, Korkmaz GG. The role of pentraxin 3 as diagnostic value in classification of patients with heart failure. Clin Biochem 2013; 46: 983-987.

12. Tazaki R, Tanigawa J, Fujisaka T, Shibata K, Takeda Y et al. Plasma Pentraxin3 Level Is Associated With Plaque Vulnerability Assessed by Optical Coherence Tomography in Patients With Coronary Artery Disease. Int Heart J 2016; 57: 18-24.

13. Ereren E, Erenler AK, Karavelioğlu Y, Kocabaş R, Erdemli HK. Ischemia-Modified Albumin is not Elevated in Deep Venous Thrombosis. Clin Lab 2015; 61: 513-516.

14. Sbarouni E, Georgiadou P, Kremastinos DT, Voudris V. Ischemia modified albumin: is this marker of ischemia ready for prime time use? Hellenic J Cardiol 2008; 49: 260-266.

15. Sinha MK, Roy D, Gaze DC, Collinson PO, Kaski JC. Role of "Ischemia Modified Albumin", a new biochemical marker of myocardial ischaemia, in the early diagnosis of acute coronary syndromes. Emerg Med J 2004; 21: 29-34.

16. Aggarwal K, Seth S, Dahiya K, Aggarwal HK, Aggarwal MK. Ischemia modified albumin in patients of cardiac and noncardiac chest pain. Biomed Res 2011; 23: 61-65.

17. Cichota LC, Moresco RN, Duarte MM, da Silva JE. Evaluation of ischemia-modified albumin in anaemia associated to chronic kidney disease. J Clin Lab Anal 2008; 22: 1-5.

18. Turedi S, Cinar O, Yavuz I, Mentese A, Gunduz A, Karahan SC, et al. Differences in ischemia-modified albumin levels between end stage renal disease patients and the normal population. J Nephrol 2010; 23 : 335-340.

19. Baydin A, Amanvermez R, Çelebi HE, Tunçel ÖK, Demircan S. Pentraxin 3, ischemia-modified albumin, and myeloperoxidase in predicting a cardiac damage in acute carbon monoxide poisoning. Am J Emerg Med 2016; 34: 1927-1930. 